\title{
The framing and celebration of the American local grain movement
}

Book review by Matthew M. Mars*

Review of The New Bread Basket: How the New Crop of Grain Growers, Plant Breeders, Millers, Maltsters, Bakers, Brewers, and Local Food Activists Are Redefining Our Daily Loaf, by Amy Halloran. (2015). Published by Chelsea Green

Publishing. Available as paperback and eBook; 246 pages. Publisher's website: http://www.chelseagreen.com/bookstore/ item/the new bread basket

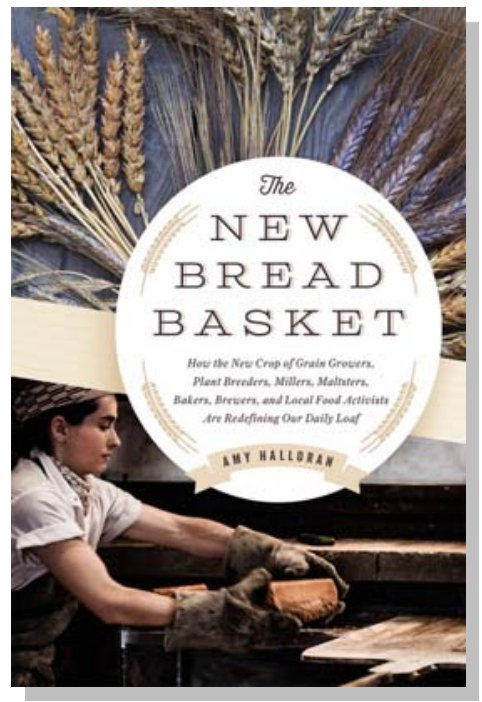

Submitted July 5, 2015 / Published online October 8, 2015

Citation: Mars, M. M. (2015). The framing and celebration of the American local grain movement [Book review]. Journal of Agriculture, Food Systems, and Community Development, 6(1), 209-211. http://dx.doi.org/10.5304/jafscd.2015.061.002

Copyright (C) 2015 by New Leaf Associates, Inc.

$\mathrm{I}^{\mathrm{n}}$ n the book The New Bread Basket: How the New Crop of Grain Growers, Plant Breeders, Millers, Maltsters, Bakers, Brewers, and Local Food Activists Are Redefining Our Daily Loaf, Amy Halloran takes readers on an imaginative tour of the revitalization

* Matthew M. Mars, Ph.D., Department of Agricultural Education, The University of Arizona; 1110 East South Campus Drive; Tucson, Arizona 85721-9889 USA; mmars@email.arizona.edu

Dr. Matthew Mars is an assistant professor of Agricultural Leadership and Innovation in the Department of Agricultural Education at The University of Arizona. Dr. Mars teaches and studies entrepreneurial strategy in the context of agricultural innovation, community leadership and social change. His current work largely centers on the diffusion of innovations across local and regional food systems and how such diffusion may or may not occur through the implementation of entrepreneurial leadership strategies. of regional grain economies within and across the United States. The harvesting, processing, preparing, and consuming of grains is at the very root of humankind and the subsequent emergence and evolution of society as we know it today. From chapter to chapter, Halloran illustrates this same capacity of regional grain production and consumption to bring people together and help form and sustain meaningful relationships in the context of contemporary local food movements.

Perhaps the most important theme to emerge from Halloran's description of the initiatives and strategies of regional grain entrepreneurs and other leaders of the revitalization movement is the importance of community and cross-functional interconnectedness to the growth and development of local food systems. The chapters that compose 
the book combine to present compelling evidence that the development of regional grain economies requires the fostering of relationships between actors who bring multiple perspectives and diverse forms of capital to common problems. Halloran demonstrates, for instance, the value of such relationships in the second chapter of the book through a description of the collaborative efforts of a farmer, miller, and baker, as well as additional local food champions, to enable the opening of a community-based mill in upstate New York. In this case, cross-trade collaboration resulted in the development of a mill that processes grains grown on the farm on which it is located, as well as from other farms across the surrounding region. In turn, local bakers are now better able to bake with locally sourced and milled flour, which is also being sold to urban customers through New York City farmers' markets. The ability of diverse stakeholders to connect and collaborate proved vital to the mill's success, as well as the farmers, bakers, and markets located both upstream and downstream from it. This case clearly illustrates the importance of intimate relationships between local food entrepreneurs and leaders positioned across local food supply chains in overcoming problems of scale in production, crop availability, and reliability, access to markets of adequate size, and other challenges. The value of such cross-system collaboration is consistently shown by many of the other cases presented throughout the book.

Halloran also demonstrates the importance of interconnectedness across communities of practice when describing in detail the development and expansion of both the Washington State University Bread Lab and the Hudson Valley Farm Hub. Through these two examples, readers are able to see how synergy among grain farmers, local food entrepreneurs, academia, government agencies, and even to some degree the commodity-based agricultural industry is able to breathe innovation and life into otherwise struggling regional grain economies. Further evidence of the importance of actor interconnectedness and diversity to the development of regional grain economies is made evident through many of the other stories Halloran shares from chapter to chapter. Two such additional examples include Michael O'Malley, an artist turned mobile oven designer, who provides energy and inspiration to the home baker movement in Southern California, and the Maine Grain Alliance, which brings volunteers, community leaders, educators, and experts from around the nation together in support of revitalizing its regional grain economy. Overall, Halloran does a masterful job of weaving stories together to illuminate the importance of human connectedness and relationships to the revitalization of regional grain economies and the diverse businesses that are beginning to thrive within them.

Convincing examples of the efforts of bakers, brewers, farmers, and millers to build momentum for regional grain consumption by reaching customers through outreach and education activities are found throughout The New Bread Basket. However, Halloran also develops persuasive examples of the importance of craftspersons educating craftspersons to support production, as was the case when Andrew Heyn of Elmore Mountain Bread "cast his net for advice" to gain input and guidance from like-minded bakers and millers on the design and building of a custom, in-house mill. More formal institutions are also shown to be vital in creating and disseminating the knowledge needed to advance regional grain revitalization initiatives, as seen by the outreach to Central New York grain farmers provided by Cornell University and Cornell Cooperative Extension through the region's food hub. Education empowers communities. Halloran underscores the truth and relevancy of this statement for readers in the direct context of regional grain production and consumption through the cases of knowledge co-creation and dissemination she develops throughout the book.

The New Bread Basket is a worthwhile addition to the local food system development literature. However, it is not without limitations. First, Halloran moves from what seems to be a mostly anthropological exploration of "off the grid" staple crop activities and initiatives to unnecessarily complex explanations of the scientific properties of grains. This is especially the case in the chapter dedicated to the biological and chemical processes associated with the human digestion of gluten. Halloran's effort to counter the popular attack on wheat products through a scientific argument that illustrates the overlooked differences between 
authentic grain products and those that are overprocessed is admirable. Unfortunately, the punch line is overshadowed by the scientific complexities that are likely to be lost on the mainstream reader.

Second, the claim made throughout the book that regional grain economies are the keystones of local food movements is overexaggerated and at times fanatical in nature. For example, Halloran proclaims at the very beginning of the book that, "as people work to regionalize food production, staples like grains are the last piece in the locavore puzzle to be solved" (p. 2). This proclamation left me searching for compelling evidence that I did not find in the book. Moreover, Halloran's fanaticism, while sometimes contagious, unnecessarily casts a shadow over the many other exciting and equally important activities and initiatives being led by entrepreneurial farmers, processors, restaura- teurs, and others that extend beyond grain. For example, she states at one point, "To be able to connect with the person who grows your cucumbers or cheese is great. To be able to connect with the people who grow your flour is better than great, because it is such a novelty and an education" (p. 137). A statement such as this one is unfortunate, as Halloran is clearly capable of making a strong case for the dynamic and intimate value of regional grains without diminishing the invaluable contributions of other local food system inputs.

Despite a few limitations, The New Bread Basket provides a set of cases and stories that are both engaging and impactful, and will leave readers with a greater appreciation for the role of regional grain economies in bolstering the viability and vitality of the movement to relocalize food. 